\title{
PENGIMPLEMENTASIAN PENDIDIKAN KARAKTER DALAM PEMBELAJARAN IPS DI KELAS INKLUSI SMP NEGERI 39 SEMARANG
}

\author{
Winda Nur Azizah, Puji Lestari ${ }^{\bowtie}$
}

Prodi Pendidikan IPS, Fakultas Ilmu Sosial, Universitas Negeri Semarang, Indonesia

\begin{tabular}{l}
\hline Info Artikel \\
\hline Sejarah Artikel: \\
Disubmit: Januari 2021 \\
Direvisi: Februari 2021 \\
Diterima: Maret 2021 \\
\hline Keywords: \\
Implementation, \\
Character Education, \\
Social Studies Learning, \\
Inclusion Class
\end{tabular}

\begin{abstract}
Abstrak
SMP Negeri 39 Semarang merupakan salah satu sekolah inkusi di Kota Semarang. Sekolah inklusi dianggap sarana yang tepat dalam pengimplementasian pendidikan karakter. Pengimplementasian pendidikan karakter dapat dilakukan melalui pembelajaran IPS agar peserta didik mampu beradaptasi dengan lingkungan dan berbekal karakter yang baik. Metode yang digunakan dalam penelitian ini adalah kualitatif deskriptif dengan teknik pengumpulan data menggunakan observasi, wawancara dan, dokumentasi. Hasil penelitian ini menunjukkan bahwa (1) Pengimplementasian pendidikan karakter di sekolah ini dilakukan melalui kegiatan pembelajaran, kegiatan pembiasaan dan kegiatan pengembangan diri. (2) Pengimplementasian pendidikan karakter ke dalam pembelajaran IPS di kelas inklusi dilakukan melalui tahap perencanaan, pelaksanaan dan evaluasi yang semuanya terintegrasi dengan pendidikan karakter. (3) Ditemukan faktor pendorong dalam pengimplementasian pendidikan karakter yakni sarana dan prasarana mendukung, program sekolah mendukung, dan sumber daya manusia yang ikut andil dalam pengimplementasian nilai karakter. Faktor penghambatnya adanya pandemi virus corona, kurang terintegrasinya pendidikan karakter di sekolah dengan di rumah, kurangnya pihak yang mengawasi perilaku dan karakter peserta didik.
\end{abstract}

\begin{abstract}
SMP Negeri 39 Semarang is one of the inclusion schools in the city of Semarang. Inclusion schools are considered to be the right means of implementing character education. The implementation of character education can be done through social studies learning so that students are able to adapt to the environment and several good characters. The method used in this research is descriptive qualitative with data collection techniques using observation, interviews and, documentation. The results of this study indicate that (1) The implementation of character education in this school is carried out through learning activities, familiarization activities and self-development activities. (2) The implementation of character education into social studies learning in the inclusive class is carried out through the planning, implementation and evaluation stages which are all integrated with character education. (3) There are driving factors in the implementation of character education including supporting facilities and infrastructure, supporting school programs, and human resources who take part in implementing character values. The inhibiting factor is the existence of the corona pandemic virus, the lack of integration of character education at school and at home, the lack of parties who supervise the behavior and character of students.
\end{abstract}

(C) 2021 Universitas Negeri Semarang

\footnotetext{
Alamat korespondensi:

Gedung C1, Lantai 1, FIS UNNES

Kampus Sekaran, Gunungpati, Semarang, 50229

Email: pujilestarikrisbiyantoro@mail.unnes.ac.id
}

E-ISSN 2685-4929 


\section{PENDAHULUAN}

Pendidikan merupakan salah satu hal yang penting dalam setiap kehidupan manusia yang tidak bisa ditinggalkan, dan setiap manusia berhak dan wajib mendapatkan pendidikan. Pemerintah dalam upaya melakukan pemerataan pendidikan termasuk bagi anak berkebutuhan khusus dengan melakukan penyatuan dengan anak reguler di sekolah agar selalu menghargai keberagaman dan tidak diskriminatif. Pemerintah merancang sistem pendidikan inklusi yang diharapkan semua anak baik anak biasa maupun yang memiliki kebutuhan khusus dapat mengembangkan potensi yang dimilikinya tidak hanya kognitif, psikomotorik tetapi juga karakter yang akan dimiliki agar ketika sudah terjun dilingkungan masyarakat sudah memiliki bekal baik pengetahuan, ketrampilan dan karakter yang baik.

Pada pembelajaran di sekolah inklusi, peran pendidik dalam pembelajaran sangat penting agar antara anak regular dan berkebutuhan khusus tidak ada perbedaan. Pendidik dalam melaksanakan pembelajaran di kelas harus menerapkan prinsip-prinsip sekolah inklusi dengan baik menurut Direktoral PLB (2010), yaitu (1) Motivasi; (2) Latar; (3) Keterarahan; (4) Hubungan sosial; (5) Belajar sambil bekerja; (6) Individualis; (7) Menemukan; (8) Pemecahan masalah. Penerapan sekolah inklusi sudah tersebar di Kota Semarang salah satunya di SMP Negeri 39 Semarang.

Pada tahun 2017 SMP Negeri 39 Semarang mendapat mandat dari dinas pendidikan untuk menerima peserta didik dengan kebutuhan khusus. Peserta didik berkebutuhan khusus dan peserta didik reguler di sekolah ini dijadikan satu dan berada di dalam satu kelas yang sama serta mendapatkan fasilitas yang sama. Di SMP Negeri 39 Semarang memiliki 3 peserta didik yang berkebutuhan khusus dengan karakteristik autism, lamban belajar, dan retardasi mental ringan. Sebagai salah satu sekolah inklusi di Kota Semarang, SMP Negeri 39 Semarang juga berupaya melaksanakan pendidikan karakter kepada peserta didiknya melalui berbagai aspek kegiatan yang ada di sekolah, baik dalam kegiatan di dalam kelas melalui pembelajaran mata pelajaran IPS maupun kegiatan di luar kelas seperti ekstrakurikuler dan lainnya.

Rumusan masalah dalam penelitian ini adalah (1) Bagaimana pengimplementasian pendidikan karakter di sekolah inklusi SMP negeri 39 Semarang?; (2) Bagaimanakah pengimplementasian pendidikan karakter dalam pembelajaran IPS di kelas inklusi SMP Negeri 39 Semarang?; (3) Apa saja faktor pendorong dan penghambat proses pengimplementasian pendidikan karakter dalam pelajaran IPS di kelas inklusi SMP Negeri 39 Semarang?.

Penelitian ini bertujuan untuk mengetahui: 1) pengimplementasian pendidikan karakter di sekolah inklusi SMP Negeri 39 Semarang; 2) pengimplementasian pendidikan karakter dalam pembelajaran di kelas inklusi IPS di SMP Negeri 39 Semarang; 3) faktor pendorong dan penghambat pengimplementasian pendidikan karakter dalam pembelajaran di kelas inklusi IPS di SMP Negri 39 Semarang.

\section{METODOLOGI}

Penelitian ini menggunakan pendekatan kualitatif. Metode penelitian kualitatif adalah metode yang digunakan untuk meneliti pada kondisi obyek yang alamiah, (sebagai lawannya adalah eksperimen) dimana peneliti adalah sebagai instrument kunci, Teknik pengumpulan data dilakukan secara triangulasi (gabungan), analisis data bersifat induktif, dan hasil penelitian lebih menekankan makna daripada generalisasi (Sugiyono, 2016).

Penelitian ini dilaksanakan di SMP Negri 39 Semarang karena berdasarkan hasil studi pendahuluan peneliti dengan melakukan wawancara kepada guru dijelaskan bahwa di SMP Negri 39 Semarang menjadi bagian dari salah satu sekolah inklusi di Kota Semarang.

Di SMP Negeri 39 Semarang terdapat tiga anak yang memiliki kebutuhan khusus yaitu Raditya kelas VIII G berjenis autism, Selly kelas 
VIII D berjenis slow learner (lamban dalam menerima materi pembelajaran), dan Salma kelas VIII H berjenis slow learner (lamban menerima materi pembelajaran). Anak berkebutuhan khusus memiliki kelas yang berbeda karena berdasarkan arahan dari dinas pendidikan agar setiap anak berkebutuhan khusus itu diharapkan mampu berinteraksi dengan peserta didik biasa. Selain itu, dalam kegiatan baik di dalam kelas maupun di luar kelas, SMP Negri 39 Semarang selalu memasukkan pendidikan karakter baik secara tertulis maupun berupa sikap. Pendidikan Karakter dalam kegiatan di kelas salah satunya melalui mata pelajaran IPS.

Teknik pengumpulan data yang digunakan adalah observasi, wawancara dan dokumentasi. Observasi dilakukan oleh peneliti untuk mendapatkan data terkait dengan proses pengimplementasian pendidikan karakter dalam pembelajaran IPS di kelas inklusi yang dilakukan guru, dan faktor yang mempengaruhi dilaksanakan pengimplementasian pendidikan karakter pada proses pembelajaran di kelas inklusi SMP Negeri 39 Semarang. Wawancara dilakukan kepada beberapa informan seperti guru IPS yang mengajar di kelas yang terdapat anak berkebutuhan khusus dan juga siswa yang berada satu kelas dengan anak berkebutuhan khusus tersebut. Dokumentasi digunakan untuk mengetahui data-data dari sekolah inklusi SMP Negri 39 Semarang bentuk pendidikan karakter yang diterapkan di sekolah inklusi terhadap siswa berkebutuhan khusus dan siswa biasa di sekolah ini.

\section{HASIL DAN PEMBAHASAN}

\section{Pendidikan Karakter di Sekolah Inklusi}

Pengimplementasian Pendidikan karakter pada peserta didik yang terintegrasi dalam kegiatan pembelajaran

Guru wajib menyusun perangkat pembelajaran yang sesuai degan kurikulum 2013. Di dalam kurikulum 2013 sangat diutamakan dalam segi penguatan karakter, maka guru dalam pembuatan RPP harus memunculkan nilai karakter di dalamnya. RPP tersebut harus dapat dijadikan acuan dalam mengembangkan karakter peserta didik.

Selain dalam perencanaan nilai karakter juga terealisasikan sesuai dengan RPP pembelajaran IPS yaitu dengan menggunakan metode keteladanan, metode pendekatan secara personal, metode nasehat, dan metode pembiasaaan. Menurut Mulyasa (2018) model pembelajaran berkarakter dapat dilakukan dengan berbagai model yaitu pembiasaan, keteladanan dan pembinaan. Di dalam kurikulum 2013 peserta didik dituntut untuk lebih aktif dan guru hanya bertugas fasilitatori saja. Agar lebih dipahami peserta didik biasanya guru mengaitkan materi yang dipelajari dengan contoh di kehidupan nyata. Salah satu upaya dalam pengimplementasian pendidikan karakter yang dilakukan oleh Guru IPS di SMP Negeri 39 Semarang adalah dengan memberikan tugas yang disesuaikan dengan materi pembelajaran dan nilai-nilai karakter yang ada di RPP. Upaya dalam mengimplementasikan pendidikan karakter tidak hanya dilakukan oleh guru saja tetapi semua stakeholder yang ada di sekolah ikut mengambil peran dalm mengimplementasikan pendidikan karakter.

Pengimplementasian Pendidikan karakter pada peserta didik melalui kegiatan pengembangan diri

Kegiatan pengembangan diri di SMP Negeri 39 Semarang bertujuan untuk mengembangkan bakat, minat, dan mengekspresikan diri peserta didik serta merupakan implementasi pendidikan karakter. Kegiatan pengembangan diri tersebut antara lain.

1) Kegiatan pelayanan bimbingan konseling, kegiatan ini memberikan fasilitas bagi peserta didik secara individu atau kelompok dapat mengatasi masalah dalam kehidupan pribadi, kemampuan sosial, kemampuan belajar, dan perencaan karir.

2) Kegiatan Pengembangan pribadi dan kreatifitas, kegiatan ekstrakulikuler di SMP Negeri 39 Semarang dapat dikelompokkan menjadi beberapa yaitu:

a) Keagamaan, yaitu: kegiatan ini dimaksudkan untuk membentuk peserta didik menjadi manusia beriman dan 
bertaqwa kepada Tuhan YME. Seperti melalui ekstra BTA dan Rohis.

b) Keolahragaan, yaitu: kegiatan untuk mengembangkan sikap sportifitas, menjaga jasmani serta rohani, serta dapat bekerjasama dalam tim. Hal ini dapat dikembangkan melalui ekskul futsal, bola volley, basket, pencak silat, dan tae kwon do.

c) Kepemimpinan, yaitu: kegiatan pengembangan di bidang kepemimpinan dimaksudkan untuk meningkatkan kesaran dan wawasan peserta didik akan status, hak, dan kewajibannya dalam hidup bermasyarakat dan berbangsa. Kesadaran akan hak dan kewajibannya sebagai warga negara yang selalu berjiwa patriot, nasionalis, berjiwa sosial, menghormati hak dan kewajiban orang lain, menghargai perbedaan dan tanggung jawab. Hal ini bisa dikembangkan melalui ekstrakulikuler paskibra, pramuka, dan PMR.

d) Seni, yaitu: kegiatan pengembangan di bidang seni untuk melatih dan mengembangkan potensi serta kemampuan peserta didik di bidang kesenian. Direalisasikan dalam seni lukis, seni tari, dan paduan suara.

e) Kelompok ilmiah remaja, yaitu: kegiatan pengembangan diri dan kreatifitas peserta didik untuk bisa mengembangkan kreatifitas, kepekaan lingkungan yang dituangkan menjadi karya ilmiah. Contoh: Jurnalistik dan karya ilmiah.

Pengimplementasian pendidikan karakter melalui kegiatan ekstrakulikuler diharapkan dapat menyempurnakan hasil belajar peserta didik yang tidak hanya pada ranah pengetahuan tetapi juga pada penerapan nilai budaya dan karakter peserta didik. Selain itu kegiatan ekstrakulikuler juga adalah kegiatan pengembangan diri. Agar menciptakan sumber daya manusia yang berkualitas dan berkuantitas.

\section{Pengimplementasian Pendidikan Karakter pada peserta didik melalui pengembangan budaya sekolah atau pembiasaan}

Pengembangan budaya sekolah di SMP Negeri 39 Semarang dilakukan melalui beberapa kegiatan dengan memuat 5 nilai utama dalam pendidikan karakter yang sesuai dengan Pancasila yaitu Religius, Nasionalis, Integrasi, Mandiri, Gotong Royong.

1) Kegiatan rutin (pembiasaan), yaitu: kegiatan yang dilakukan peserta didik secara terus menerus dan konsisten, misalnya upacara bendera setiap hari senin, memunculkan karakter nasionalis dan solat berjamaah memunculkan karakter religius. Kegiatan pembiasaan di sekolah sangat penting diberikan secara rutin untuk membentuk karakter peserta didik, hal ini sesuai dengan Mulyasa (2018) Kegiatan pembiasaan dapat mendorong mempercepat perilaku dan tanpa pembiasaan hidup seseorang akan berjalan lama sebab sebelum melakukan sesuatu harus memilikirkan terlebih dahulu apa yang harus dilakukan.

2) Kegiatan spontan, yaitu: kegiatan yang dilakukan peserta didik secara spontan pada saat itu juga. Misal menggalang dana bagi korban bencana dan menyalurkannya karena kepedulian sosial peserta didik ingin ikut membantu dari kegiatan tersebut memunculkan nilai karakter gotong royong.

3) Keteladanan, yaitu: sikap dan perilaku dalam memberikan contoh melalui tindakantindakan yang baik sehingga dapat dijadikan keteladanan bagi peserta didik. Misalnya guru menjadi suri tauladan bagi siswanya, ketika guru mencontohkan hal baik maka siswa akan mencoh perbuatan tersebut. Hal ini sesuai dengan pendapat Mulyasa (2018) model pembelajaran berkharakter dapat dilakukan dengan berbagai model salah satunya adalah keteladanan.

4) Pengkondisian lingkungan, yaitu: penciptaan kondisi dilingkungan yang mendukung guna mengimplementasian pendidikan karakter di kelas inlusi SMP Negeri 39 Semarang. Kondisi lingkungan yang mendukung akan mempengaruhi pembentukan karakter peserta didik. Sesuai dengan penyataan Gunawan (2014) bahwa salah satu faktor intern yang mempengaruhi pembentukan karakter adalah lingkungan. 
Pengimplementasian pendidikan karakter dalam pembelajaran IPS di kelas inklusi SMP Negeri 39 Semarang

\section{Perencanaan Pembelajaran}

Guru membuat perangkat pembelajaran yang berupa program tahunan, program semesteran, silabus, Rencana Pelaksanaan pembelajaran (RPP). Pengimplementasian Pendidikan Karakter kedalam pembelajaran IPS dapat dilihat dari Rencana Pelaksanaan Pembelajaran (RPP) yang dibuat oleh guru di awal tahun ajaran sebagai syarat kelengkapan administrasi pembelajaran yang harus dilengkapi. Setiap RPP yang dibuat selalu mencantumkan nilai-nilai karakter yang akan dimunculkan dalam kegiatan inti pembelajaran. Mulyasa (2018) menyatakan RPP berkarakter berfungsi untuk mengefektifkan proses pembelajaran dan pembentukan karakter peserta didik disesuaikan dengan RPP dan bahan ajar. Sebagai sekolah inklusi, SMP Negeri 39 Semarang memiliki 2 RPP yang bermuatan pendidikan karakter yaitu RPP untuk peserta didik reguler dan RPP untuk peserta didik yang berkebutuhan khusus.

\section{Pelaksanaan Pembelajaran}

Pada pelaksanaan kegiatan pembelajaran ini guru menerapkan model discovery learning (model pembelajaran yang terjadi ketika peserta didik tidak disajikan informasi secara langsung, tetapi peserta didik dituntut untuk memahami informasi tersebut secara mandiri). Tetapi dalam keadaan pendemi corona seperti ini pengimplementasian pendidikan melalui pembelajaran terhambat karena dalam mengimplementasikan nilai-nilai karakter terhadap pesert didik diperlukan interaksi secara langsung. Berhubung kondisi pembelajaran sekarang ini dilakukan secara daring (dalam jaringan), maka pengimplementasian pendidikan karakter dalam pembelajaran IPS kepada peserta didik menyesuaikan situasi dan kondisi yang ada di SMP Negeri 39 Semarang. Menurut Kementrian Pendidikan Nasional ada beberapa prinsip untuk mewujudkan pendidikan karakter yang efektif salah satunya adalah memfungsikan keluarga dan anggota masyarakat sebagai mitra dalam usaha membangun karakter. Bagi peserta didik yang berkebutuhan khusus pembelajaran daringnya dilakukan dengan koordinasi anatara wali kelas dengan wali murid agar dapat mendampingi peserta didik yang berkebutuhan khusus sehingga dapat menyesuaikan dengan pembelajaran secara daring. Dalam implementasi pendidikan karakter di kelas inklusi maupun kelas reguler secara mendasar tidak ada perbedaan dikarenakan pendidikan inklusi memandang persamaan namun dalam pelaksanaannya dikelas inklusi guru lebih menekankan karakter kepedulian untuk siswa reguler yang bertujuan agar siswa reguler yang ada di kelas inklusi lebih memahami keadaan siswa berkebutuhan khusus dan untuk siswa berkebutuhan khusus guru menekankan pada sikap percaya diri agar siswa mampu mengembangkan potensi yang ada dalam dirinya.

\section{Evaluasi Pembelajaran}

Pelaksanaan terkait evaluasi pengimplementasian pendidikan karakter dalam pembelajaran IPS di kelas inklusi SMP negeri 39 Semarang dilakukan dengan memperhatikan indikator tertentu yang sesuai dengan tujuan dari RPP dalam melakukan penilaian sikap. Teknik dan instrumen yang dipilih dan dibuat tidak hanya mengukur pencapaian akademik peserta didik baik reguler maupun peserta didik inklusi saja tetapi juga mengukur perkembangan kepribadian peserta didik secara keseluruhan yang disesuaikan dengan indikator dalam RPP. Pengimplementasian pendidikan karakter ke dalam pembelajaran IPS di kelas inklusi pada tahap penilaian dilakukan melalui observasi. Guru IPS mengimplementasikan pendidikan karakter ke dalam pembelajaran IPS pada tahap penilaian pembelajaran dilakukan dengan membuat form penilaian. Pembuatan form penilaian tidak memiliki aturan baku. Setiap guru memiliki kriteria berbeda dalam pembuatan form penilian. Secara umum, form penilaian biasanya berisi no, nama peserta didik, aspek yang dinilai, skor atau nilai. Untuk form 
penilaian di RPP inklusi isinya juga sama tetapi indikator pencapaiannya disesuaikan dengan assessment yang dimiliki peserta didik. Dari hasil penilaian sikap dalam pembelajaran IPS peserta didik di kelas inklusi SMP Negeri 39 Semarang sudah memiliki sikap yang baik dari beberapa indikator penilaian rata-rata nilai yang diperoleh yaitu 3 artinya baik. nilai sikap yang baik diharapkan juga pesesta didik memiliki karakter yang baik.

Faktor Pendorong dan Penghambat Pengimplementasian Pendidikan Karakter dalam Pembelajaran IPS Di Kelas Inklusi SMP Negeri 39 Semarang

Faktor pendorong dalam pengimplementasian pendidikan karakter dalam pembelajaran IPS di kelas inklusi SMP Negeri 39 Semarang adalah: 1) sumber daya manusia, dalam pelaksanaan pengimplementasian pendidikan karakter di SMP telah berjalan sesuai peran dari seluruh masyarakat yang ada di sekolah. Baik Kepala sekolah, Guru, pegawai tersebut menyadari perannya dalam mengimplementasikan pendidikan karakter. $\mathrm{Hal}$ ini sesuai salah satu prinsip pendidikan karakter menurut Kemendiknas (2010) yaitu Memfungsikan seluruh staff sekolah sebagai komunitas moral yang berbagi tanggung jawab untuk pendidikan karakter dan setia pada nilai dasar yang sama. Jadi seluruh masyarakat harus saling bekerjasama dengan baik untuk membentuk karakter peserta didik; 2) program sekolah, dalam hal ini di SMP Negeri 39 Semarang terdapat beberapa peraturan yang dibuat untuk mendidik peserta didik seperti adanya peraturan kedisiplinan yaitu peserta didik harus masuk tepat pada waktunya. Hal ini sesuai dengan yang diungkapkan Gunawan (2014) bahwa Salah satu faktor eksternal yang mempengaruhi pembentukan karakter adalah pendidikan. Pendidikan yang ada di sekolah tidak hanya untuk membuat peserta didik lebih pintar tetapi juga membuat peserta didik menjadi pribadi dengan karakter yang baik; dan 3) sarana dan prasarana di SMP Negeri 39 Semarang secara umum sudah tergolong lengkap, dikarenakan sudah mampu memenuhi kebutuhan peserta didik dan menunjang dalam proses pengimplementasian pendidikan karakter.

Faktor penghambat dalam pengimplementasian pendidikan karakter dalam pembelajaran IPS di kelas inklusi SMP Negeri 39 Semarang adalah: 1) belum memiliki grand desain, dalam hal ini SMP Negeri 39 Semarang belum memiliki konsep khusus atau grand design dalam pengimplementasian pendidikan karakter, sehingga dalam pelaksanaan pendidikan karakter di SMP Negeri 39 Semarang belum berjalan secara optimal. Hal tersebut sejalan dengan pendapat Munir (2018) dimana salah faktor yang dapat menghambat pelaksanaan pendidikan karakter yakni tidak adanya suatu model, metode, strategi dan evaluasi yang berkala dalam pelaksanaan pendidikan karakter; 2) dampak virus corona pembelajaran secara daring, bencana non alam ini muncul sebagai kendala dalam implementasi pendidikan karakter karena dalam pelaksaan pendidikan karakter dilakukan sekolah dengan pengentegrasian melalui program sekolah, budaya sekolah maupun pembelajaran. Berdasarkan pendapat Munir (2018) terdapat sedikit perbedaan dimana dalam teori tidak mengklasifikasikan pandemi atau bencana non alam tersebut sebagai kendala dalam pelaksanaan pendidikan karakter namun dalam penelitian yang telah peneliti lakukan menemukan kendala becana non alam sebagai salah satu kendala dalam pelaksanaan pendidikan karakter; 3 ) peran orang tua, di sini sekolah melibatkan orangtua untuk ikut serta dalam mengembangkan karakter kepada peserta didik, hal ini bisa dilakukan dengan mengintegritaskan konsep yang diajarkan antara sekolah dengan orang tua di rumah, orang tua juga harus menjadi teladan bagi peserta didik dalam menerapkan nilai karakter. Sesuai dengan pendapat Gunawan (2014) bahwa salah satu faktor yang mempengaruhi pendidikan karakter yaitu ada di faktor intern yang keturunan. Keikutsertaan orang tua sangat berpengaruh dalam proses pembentukan karakter peserta didik; dan 4) Pengawasan dan pembinaan yang kurang, di SMP Negeri 39 Semarang terkait pengawasan dan pembinaan masih kurang 
maksimal dalam implementasi pendidikan karakter yang menandakan bahwa partisipasi pemangku kepentingan yang kurang optimal. Hal tersebut sejalan dengan Munir (2018) menjelaskan bahwa dalam penanaman pendidikan karakter terdapat suatu faktor yang dapat menghambat pelaksanaan pendidikan karakter partisipasi pemangku kepentingan yang kurang optimal.

\section{SIMPULAN}

Proses pengimplementasian pendidikan karakter di SMP negeri 39 Semarang belum memiliki dokumen khusus yang dijadikan sebagai panduan dalam pengimplementasian pendidikan karakter. Maka sebagai acuan dalam pelaksanaan pengimplementasian pendidikan karakternya menggunakan Dokumen 1 Kurikulum SMP Negeri 39 Semarang yang disusun dari hasil kesepakatan antara semua guru dan kepala sekolah serta lembaga pendidikan berisi tentang konsep dan ide-ide dalam pelaksanaan pendidikan karakter di sekolah ini.

Pengimplementasian pendidikan karakter di SMP Negeri 39 Semarang sebagai sekolah inklusi dilakukan kepada seluruh peserta didik baik yang reguler maupun yang berkebutuhan khusus. Pengimplementasian pendidikan karakternya secara umum dibagi ke dalam 3 proses, yaitu: 1) Implementasi pendidikan karakter melalui budaya yang ada di SMP Negeri 39 Semarang; 2) Implementasi pendidikan karakter yang dilakukan melalui pengembangan diri (kegiatan intrakulikuler dan ekstrakulikuler) bagi seluruh peserta didik; dan 3) pengimlementasian pendidikan karakter ke dalam kegiatan pembelajaran di seluruh mata pelajaran.

Pengimplementasian pendidikan karakter dalam pembelajaran IPS di Kelas Inklusi SMP negeri 39 Semarang dilakukan dengan melalui 3 tahapan yaitu: 1) proses perencanaan yang berisi rancangan dalam kegiatan pembelajaran.; 2) kegiatan pembelajaran di kelas, guru melaksanakan kegiatan pembelajaran yang mengacu pada RPP IPS yang yang dibuat; dan
3) proses penilaian biasanya mengacu pada RPP yang telah dibuat oleh guru.

Faktor pendorong dalam pengimplementasian pendidikan karakter dalam pembelajaran IPS di kelas inklusi SMP Negeri 39 Semarang adalah lingkungan sekolah yang menyebabkan suasana kondusif dan nyaman bagi peserta didik menjadikan proses pengimplementasian pendidikan karakter di kelas inklusi SMP Negeri 39 Semarang berjalan dengan baik, sumber daya manusia yang secara aktif berperan dalam membantu proses pengimplementasian pendidikan karakter dalam pembelajaran IPS di kelas inklusi SMP Negeri 39 Semarang, program sekolah yang baik yang disesuaikan sebagai sekolah inklusi dan sekolah ramah anak berpengaruh baik dalam pengimplementasian pendidikan karakter, dan sarana dan prasarana yang mendukung proses kegiatan pembelajaran yang ada di sekolah. Sedangkan faktor penghambatnya yakni belum adanya dokumen khusus yang berisi acuan dalam pengimplementasian pendidikan karakter, adanya pandemi virus corona saat ini mengakibatkan kegiatan sekolah dilakukan secara daring (dalam jaringan), peran orangtua yang kurang peduli menyebabkan ketidak sinkronan proses pengimplementasian pendidikan karakter, dan belum adanya tim khusus dalam memantau pengimplementasian pendidikan karakter.

\section{DAFTAR PUSTAKA}

Direktorat PLB. 2010. Pedoman Penyelenggaraan Pendidikan Terpadu/ Inklusi Manajemen Sekolah. Jakarta : Depdiknas.

Gunawan, Heri. 2014. Pendidikan Karakter. Bandung: Alfabet.

Kemendiknas Republik Indonesia. 2010. Kebijakan Nasional Pembangunan Karakter bangsa. Jakarta: Pusat Kurikulum Balitbang Kemendiknas.

Munir, dkk. 2018. Implementasi Program Pendidikan Karakter Di SMPN 2 Lilirilau 
Winda Nur Azizah, dkk / Sosiolium 3 (1) (2021)

Kabupaten Soppeng. Dalam Jurnal Ilmiah Pena Sugiyono, 2016. Metode penelitian pendidikan Vol. 1 Nomor 2 Tahun 2018.

Pendekatan Kuantitaif, Kualitatif, dan $R \& D$.

Mulyasa. 2018. Manajemen Pendidikan Karakter.

Bandung: Alfabeta.

Jakarta: PT. Bumi Aksara. 